https://nv.nltu.edu.ua

https://doi.org/10.36930/40310120

$@ \bigotimes$ Correspondence author

Article received 31.12.2020 p.

Article accepted 04.02.2021 p.

R. I. Kvit

UDC 004.9312

R. A. Melnyk, R. I. Kvit, T. M. Salo

Lviv Polytechnic National University, Lviv, Ukraine

\title{
FACE IMAGE PROFILES FEATURES EXTRACTION FOR RECOGNITION SYSTEMS
}

The object of research is the algorithm of piecewise linear approximation when applying it to the selection of facial features and compression of its images. One of the problem areas is to obtain the optimal ratio of the degree of compression and accuracy of image reproduction, as well as the accuracy of the obtained facial features, which can be used to search for people in databases. The main characteristics of the image of the face are the coordinates and size of the eyes, mouth, nose and other objects of attention. Dimensions, distances between them, as well as their relationship also form a set of characteristics. A piecewise linear approximation algorithm is used to identify and determine these features. First, it is used to approximate the image of the face to obtain a graph of the silhouette from right to left and, secondly, to approximate fragments of the face to obtain silhouettes of the face from top to bottom. The purpose of the next stage is to implement multilevel segmentation of the approximated images to cover them with rectangles of different intensity. Due to their shape they are called barcodes. These three stages of the algorithm the faces are represented by two barcode images are vertical and horizontal. This material is used to calculate facial features. The medium intensity function in a row or column is used to form an approximation object and as a tool to measure the values of facial image characteristics. Additionally, the widths of barcodes and the distances between them are calculated. Experimental results with faces from known databases are presented. A piecewise linear approximation is used to compress facial images. Experiments have shown how the accuracy of the approximation changes with the degree of compression of the image. The method has a linear complexity of the algorithm from the number of pixels in the image, which allows its testing for large data. Finding the coordinates of a synchronized object, such as the eyes, allows calculating all the distances between the objects of attention on the face in relative form. The developed software has control parameters for conducting research.

Keywords: approximation; piecewise linear function; cumulative histogram; multilevel segmentation; mean intensity.

\section{Introduction}

Multilevel threshold for image data mining is very important. However, its computational complexity in many algorithms increases exponentially with the number of thresholds. The article [1] proposes a criterion for maximizing the modified interclass variance, and a recursive algorithm is developed to efficiently find the optimal threshold using those stored in a lookup table. The paper [2] proposes a new method based on the quantum particle swarm optimization (QPSO) algorithm. In [3], starting with the extreme pixel values at both ends of the histogram plot, the algorithm is recursively applied to the sub-ranges calculated in the previous step to find the threshold level and a new subrange for the next step until a significant improvement in image quality is achieved. The article [4] proposes multilevel image thresholding for image segmentation using several recently introduced $\mathrm{P}$-metaheuristic algorithms, including whale optimization algorithm, Grey Wolf Optimizer (GWO), optimization algorithm based on teaching-learning and some others. In paper [5] a new method of multilevel thresholds for image segmentation using GWO is proposed.
This metaheuristic algorithm is applied to a multilevel threshold problem using the Kapurs entropy and Otsu methods between class variance functions.

There are many studies on facial recognition approaches. Various methods, approaches and algorithms for recognizing human faces are used by many authors, for example, PCA, LDA, artificial neural networks, wavelets, curves, kernel methods, Gabor filters, active appearance models, 2D and 3D representations. Some of them are given in [6, $7,8,9]$.

Two generations of distributed cumulative histogram are in the base of the proposed approach to determine face features in paper [10]. The rough barcodes of the face image were obtained. The clustering K-means algorithm was applied to features to get more contrast bands of color.

In this work there is an attempt to create an approach that allows you to compare faces with different brightness and obtained by different fixing sensors. It presents very fast and simple algorithms of approximation, multilevel segmentation and to apply them for face features determination. The final face model is an overlay of vertical and

\section{Інформація про авторів:}

Мельник Роман Андрійович, д-р техн. наук, професор, кафедра програмного забезпечення. Email: ramelnyk@polynet.lviv.ua; https://orcid.org/0000-0002-4329-6740

Квіт Роман Іванович, канд. фіз.-мат. наук, доцент, кафедра вищої математики. Email: roman.i.kvit@lpnu.ua; https://orcid.org/0000-0002-2232-8678

Сало Тетяна Михайлівна, канд. фіз.-мат. наук, доцент, кафедра вищої математики. Email: tetyan.salo@gmail.com; https://orcid.org/0000-0001-9469-7459

Цитування за ДСтУ: Мельник Р. А., Квіт Р. І., Сало Т. М. Виділення ознак профілів зображення обличчя для систем розпізнавання. Науковий вісник НлтУ України. 2021, т. 31, № 1. С. 117-121.

Citation APA: Melnyk, R. A., Kvit, R. I., \& Salo, T. M. (2021). Face image profiles features extraction for recognition systems. Scientific Bulletin of UNFU, 31(1), 117-121. https://doi.org/10.36930/40310120 
horizontal barcodes giving for researcher to choose a number and a type of distances for measurement and comparison of face images.

The presented investigation is relevant because contemporary systems of image processing need linear algorithmic complexity to allow searching, transferring and storing big amount of face images. The article considers one of the approaches devoted to such problems.

The object of investigation is the piecewise linear approximation applied to face images to extract their feature. The aim of the work is to minimize processing time and the size of files stored in computer networks.

Methods of research. During investigations it was used mathematical instrument of piecewise function approximation, object of cumulative histogram of images, formulas for accuracy evaluation and method for searching.

\section{Research results and their discussion}

Piecewise linear approximation by planes. To get an image profiles dependencies the simple formula of mean intensity in rows or columns is needed for it:

$$
\begin{gathered}
I_{y}(j)=\frac{1}{H} \sum_{i=1}^{H} I(i, j), \quad 1 \leq j \leq W, \\
I_{x}(i)=\frac{1}{W} \sum_{j=1}^{W} I(i, j), \quad 1 \leq i \leq H .
\end{gathered}
$$

The formulas (1) and (2) to the original face image give continuous plots with a step of one pixel. To get discrete features of an image profiles it is need another technique based on approximation by planes and segmentation.

The function $f(x)$ representing the pixels mean intensity in the interval of the width of the plane is approximated by piecewise linear function $g(x)$ defined on the interval $a_{i} \leq x_{i} \leq a_{i+1}$ with a set of sections with endpoints $\left(\alpha_{i}, \beta_{i}\right)$ and $\left(\alpha_{i+1}, \beta_{i+1}\right)$. The function $g(x)$ also displays the pixels mean intensity in the range of a plane width. The function $g(x)$ minimizes the approximation error $\varepsilon$ obtained by the following formula:

$$
\varepsilon=\max _{a_{i} \leq x \leq a_{i+1}}|g(x)-f(x)| .
$$

The approximation function is presented as:

$$
g(x)=\sum_{i=0}^{N-1} g_{i}(x)
$$

where

$$
\begin{gathered}
g_{i}(x)=\left\{\begin{array}{l}
m_{i} x+b_{i} \quad \text { for } a_{i} \leq x \leq a_{i+1}, \\
0 \quad \text { in other case }
\end{array}\right. \\
m_{i}=\frac{\beta_{i+1}-\beta_{i}}{\alpha_{i+1}-\alpha_{i}} \\
b_{i}=\beta_{i}-m_{i} \alpha_{i} \text { for } i=\overline{0, N-1}
\end{gathered}
$$

Approximation formula was realized and results for 4 and 2 widths of planes are given in Figure 1.



Fig. 1. Piecewise linear approximation of intensity integral column function of the face image $(a): b-4$ columns; $c-2$ columns
Figure 1 demonstrates that the approximation algorithm allows to get many profiles of the face image and consequently to use them for different recognition purposes. But the goal of this article is to illustrate an effect of combination of approximation and multilevel segmentation.

Determination of threshold values. For the image histogram:

$$
h(i)=\operatorname{card}\{(u, v) \mid I(u, v)=i\},
$$

the cumulative histogram is calculated:

$$
H(i)=\sum_{j=1}^{i} h(j),
$$

where $I(u, v)$ is the pixel intensity; $h(i)$ is the intensity frequency; $H(i)$ is the accumulating frequency for the given intensity.

To perform multilevel segmentation the Ramer-Douglas-Peucker (RDP) algorithm $[11,12]$ to the function $H(i)$ of the face image in Figure 1, a is applied. The number of threshold values is determined from the interval of the mean intensity function oscillations. It must allow you to demonstrate all extreme regions of the plot. The bigger number of threshold values causes the smaller dimension of barcodes and more accurate positions are determinate. So, as an example our choice is 12 threshold values. Figure 2 shows the cumulative histogram of the approximated image and 10 lines indicating the points of the approximating function.

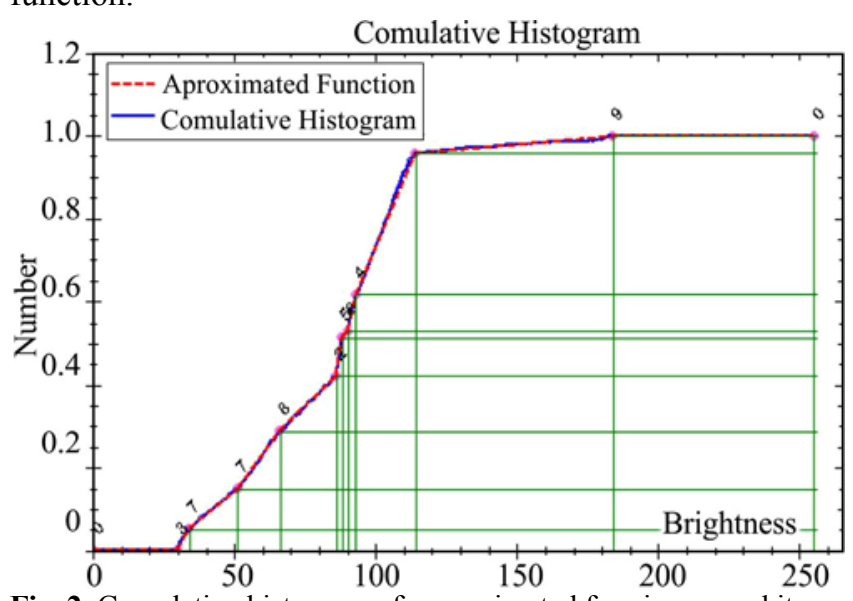

Fig. 2. Cumulative histogram of approximated face image and its approximating piecewise linear function

The final version of the approximating function has 12 points: two outside and 10 inside. The coordinates of the intensity intervals in a piecewise linear function give us four possibilities to change the color in the interval: the left or right intensity coordinates according to Figure 2, the center or weighted mean intensity value of all pixels in the interval.

So, one of four formulas can be chosen:

$$
\begin{gathered}
I_{s k}(i, j)=I_{k}(l), \quad(i, j) \in P_{k}, \\
I_{s k}(i, j)=I_{k}(r), \quad(i, j) \in P_{k}, \\
I_{s k}(i, j)=\left[I_{k}(l)+I_{k}(r)\right] / 2, \quad(i, j) \in P_{k}, \\
I_{s k}(i, j)=\frac{1}{n_{k}} \sum_{z=1}^{n_{k}} n_{k z} I_{k z}, \quad(i, j) \in P_{k} .
\end{gathered}
$$

where $k$ is the index of the intensity interval; $n_{k}$ is the number of pixels in the $k$ th interval; $I_{s k}(i, j)$ denotes the pixels of $k$ th interval of the new segmented image; $1, r$ indicate its left and right borders; $n_{k z}$ is the number of pixels 
having an intensity $I_{k z}$ in $k$ th interval; $P_{k}$ is a set of pixels belonging to $I_{k}$, i.e. the $k$ th interval.

The new image (Figure 3,b) of the approximated face now has quantized intensity values corresponding to the found threshold values. Actually by multilevel segmentation and redrawing of approximated face image new approximated image of the original face image or approximated image is obtained.



Fig. 3. Transformation of face image: $a$ - face image; $b$-approximated face image; $c$ - segmented by 12 threshold values approximated image

Formula (1) for two images in Figure 3,b and Figure 3,c gets two plots which are given in Figure 4 is applied.

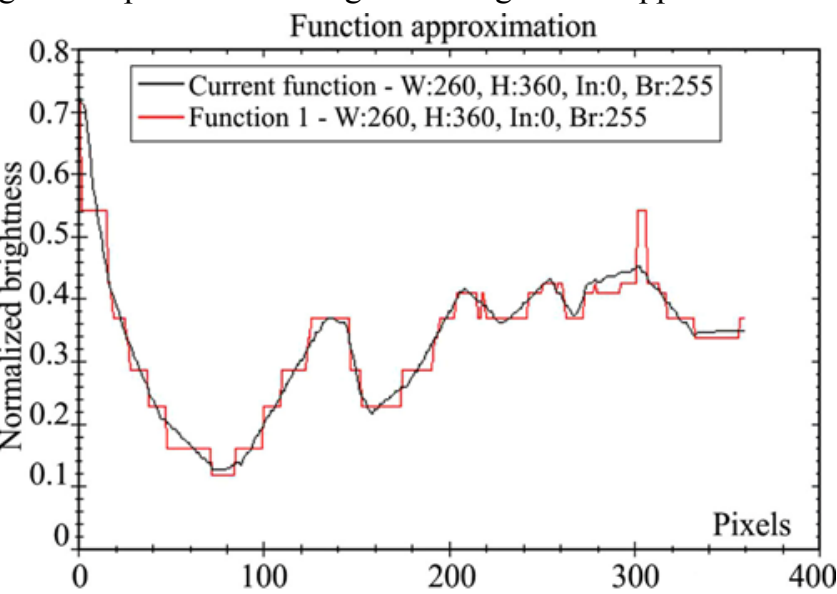

Fig. 4. Two mean intensity functions in image rows: for one column piecewise linear approximation and its multilevel segmentation

Now discrete values of the face image profile features are available for manipulation and preparing for recognition systems. Some values of the function must be amplified and some must be reduced.

Horizontal barcodes of face image. In a function $I_{y}(j)$ segments with minimal and maximal values are being searched by special procedure. Then rectangles corresponding to the segments are being marked by red (maximal) and blue (minimal) colors according to their positions (Figure $5, a)$. To make the image more contrast and independent from grey color all other rectangles by white color (Figure $5, b)$ are marked.

White color allows you to neglect less important details of faces decreasing calculation needed for searching and classification.

Having the image of multilevel segmentation with marked main rectangles it is possible to find and highlight them and formulate the face image feature based on the mean intensity function in rows in Figure 6. If only minimal rectangles are remained, so-called barcodes of the face image are obtained.

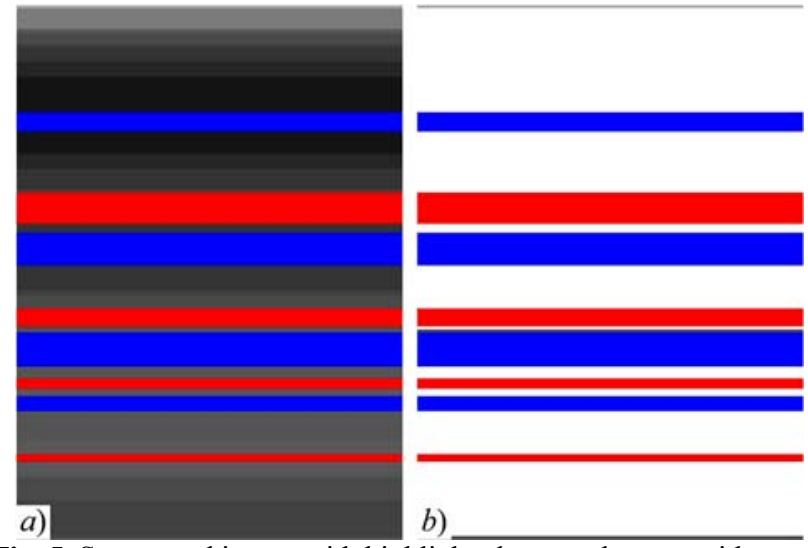

Fig. 5. Segmented image with highlighted rectangles: $a$ - with grey background; $b$ - with white background

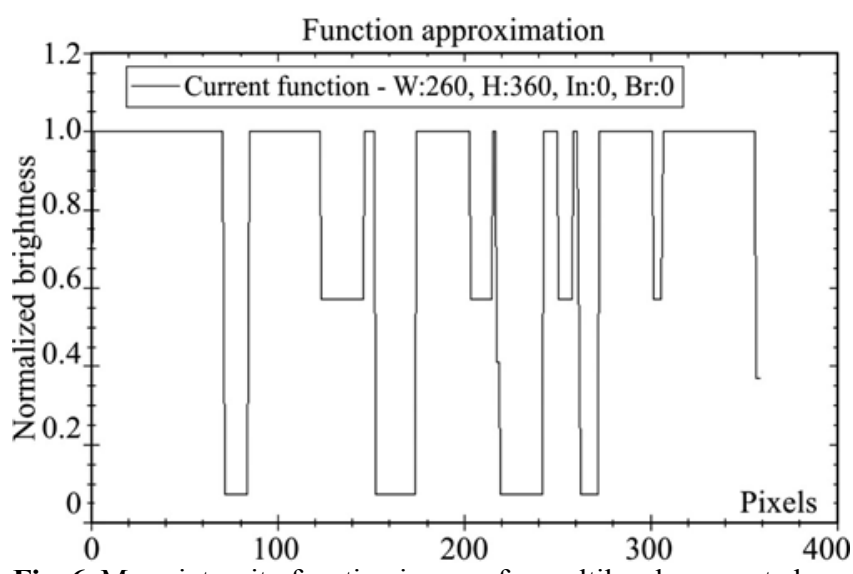

Fig. 6. Mean intensity function in rows for multilevel segmented

image with marked rectangles of maximal and minimal intensity

An overlay of the original face image and marked rectangles illustrates correspondence of blue and red rectangles to the face parts in Figure 7. Overlay of the original face image and its horizontal barcodes obtained by 7 numbers of segmentation levels is shown in Figure 7,a.

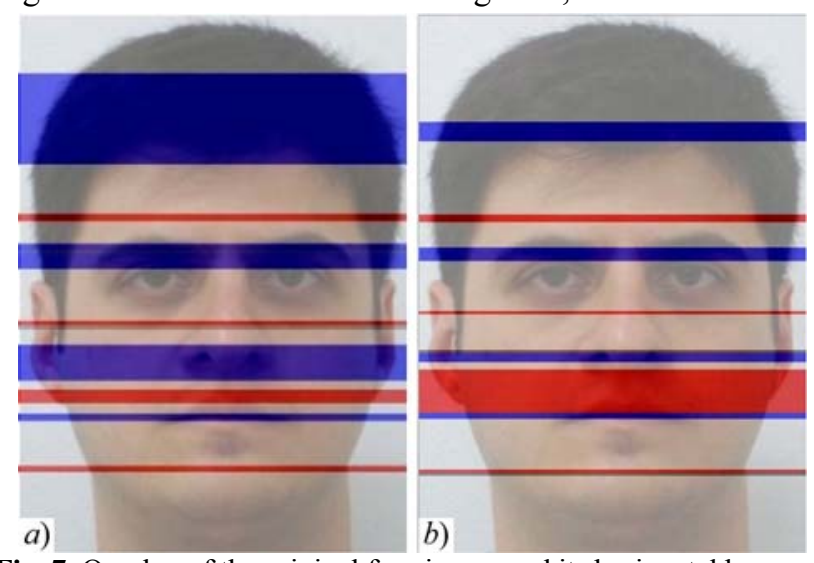

Fig. 7. Overlay of the original face image and its horizontal barcodes obtained by different numbers of segmentation levels: $a-7$ levels; $b-10$ levels

If the greater number of segmentation levels are needed, blue indicating rectangles will be thinner (Figure 7,b).

Vertical barcodes. Having coordinates of the main horizontal rectangles of the face image and their height a set of vertical rectangles connected with previous ones can be obtained. These values indicate what corresponding rows of the face image must be chosen as the objects of piecewise linear approximation.

As an example the rectangle containing eyes are used. The process has the following steps: cropping the rectangle 
image by earlier founded coordinates (Figure 8,a), approximation of the image by the flat planes (Figure 8,b) with the RGP algorithm, multilevel segmentation by 12 or more levels by piecewise linear approximation of the cumulative histogram (Figure 8,c).

a)

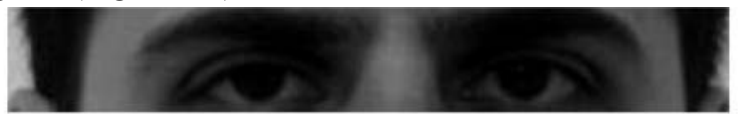

b)
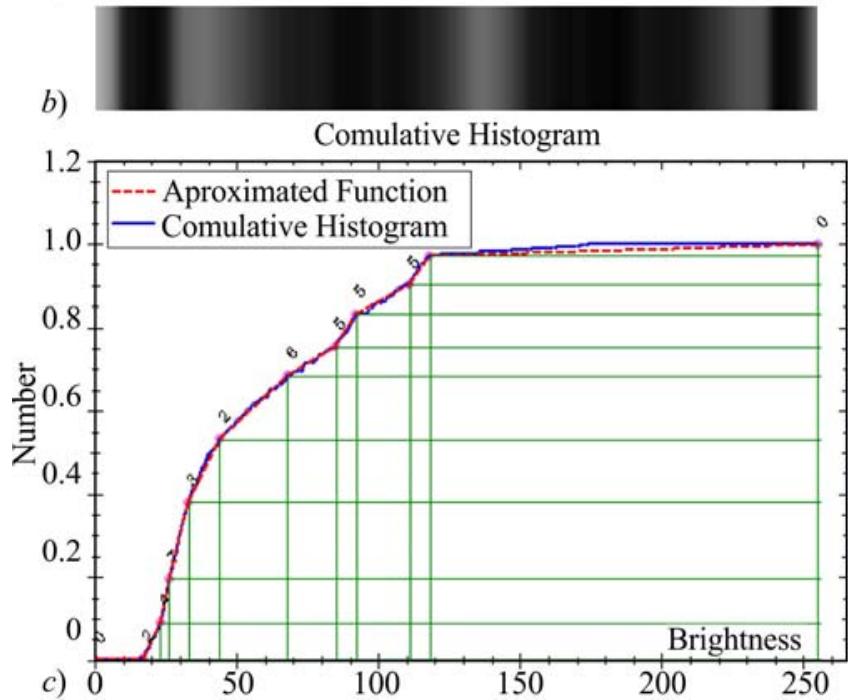

Fig. 8. Fragment of face: $a$-cropped part of the face image; $b-$ approximated by piecewise linear planes; $c$ - multilevel segmentation of its cumulative histogram

Multilevel segmentation and redrawing segments by formulas (10)-(13) give us segments as rectangles of new colors (Figure 9,a). Rectangles having maximal and minimal values of mean intensity function (2) are being redrawn in red and blue colors (Figure 9,b), all other segments-rectangles are marked by white color (Figure 9,c).

a)

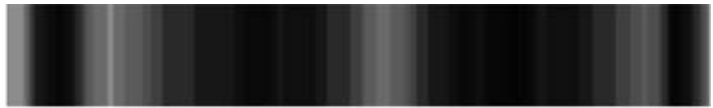

b)



c)

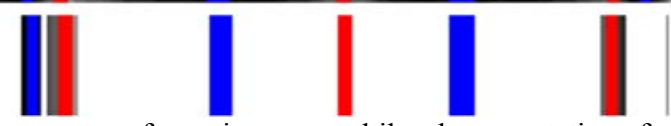

Fig. 9. Features transformation: $a$ - multilevel segmentation of piecewise linear approximated image; $b$-segmented image with highlighted rectangles with grey background; $c$ - colored bars with white background

In Figure 10, $a$ mean intensity function in columns illustrates changed colors of rectangles having extreme values of mean intensity function. In Figure $10, b$ we see the same function for white-blue-red image.

Two overlays as final result are used: of the original face image and horizontal barcodes with vertical barcodes of eyes in Figure 11, $a$ and of the original face image with main vertical and horizontal barcodes in Figure 11,b.

Images comparison by barcodes. Comparison of face images by barcodes had the following advantages: the calculation process is of linear complexity and depends of the model type (horizontal, vertical bars for one, two and more column models), the intensity dependence is absent and calculation of the criteria function is simple.

Let us consider in Figure 12 three closest face images from [13].
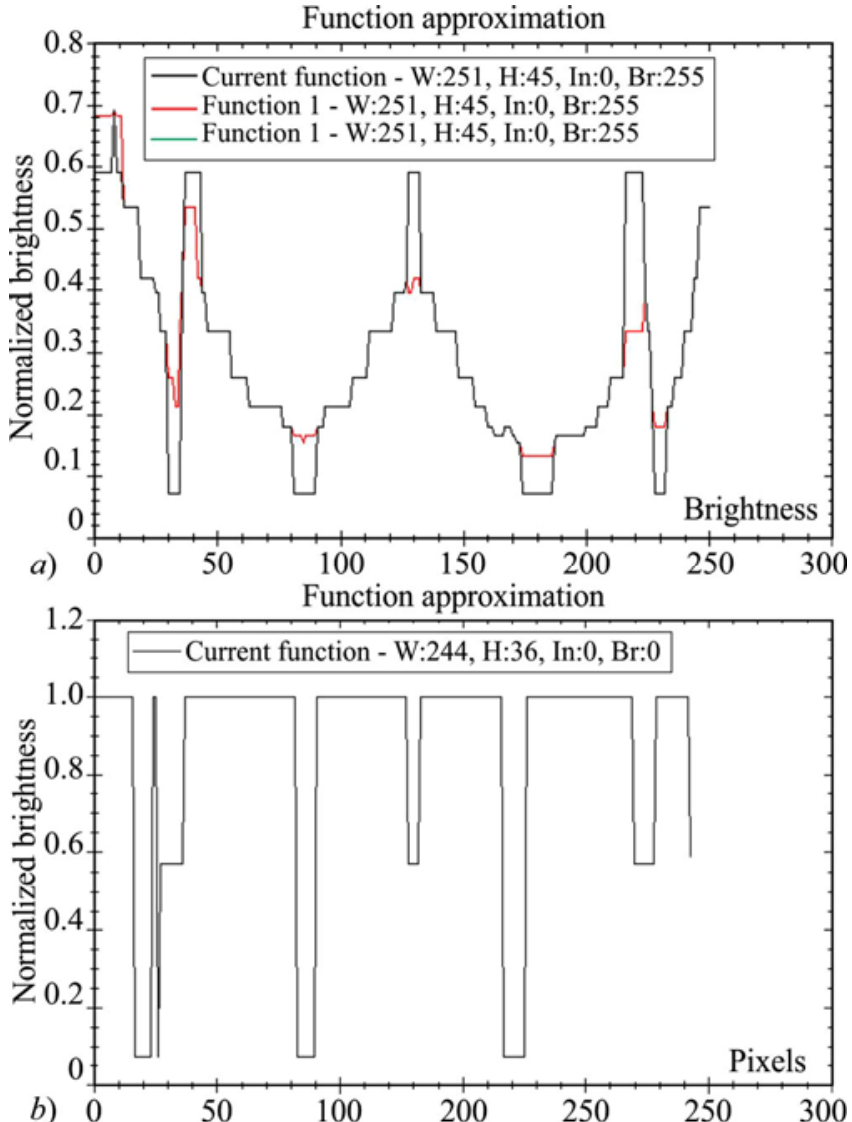

Fig. 10. Two mean intensity functions: $a$ - for segmented and colored rectangles; $b$ - with white background
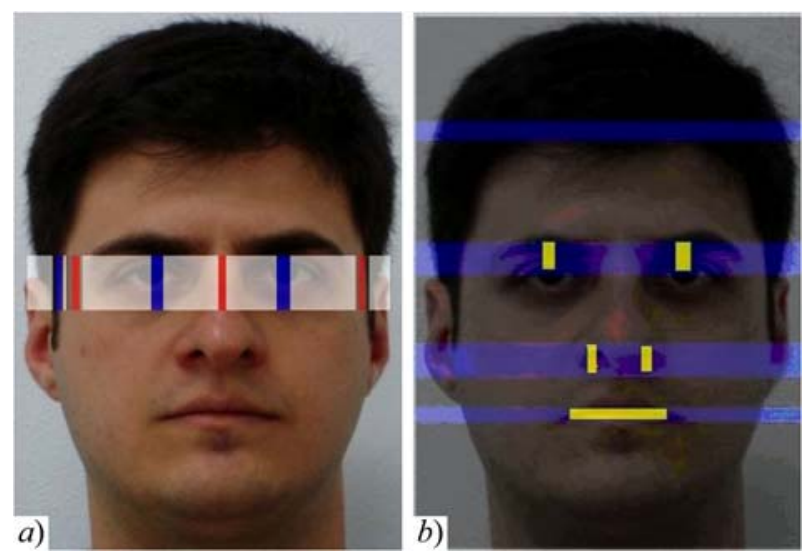

Fig. 11. Two overlays of the original face image: $a$-with one horizontal barcode; $b$ - with vertical barcodes within horizontal barcodes
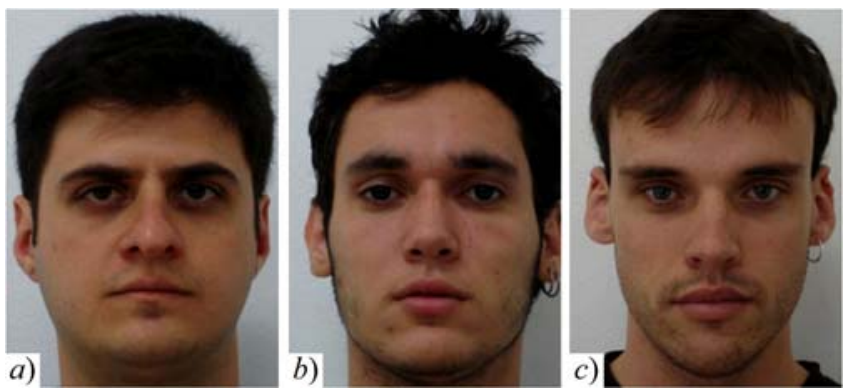

Fig. 12. Three faces for comparison: $a-1 \mathrm{a} ; b-7 \mathrm{a} ; c-17 \mathrm{a}$

For their comparison we use the traditional similarity function:

$$
D_{i j}=\frac{1}{N} \sum_{x=1}^{N}\left|f_{i}(x)-f_{j}(x)\right|
$$


which was applied for mean intensity in rows for approximated and segments images. Three values of the function (14): $D_{12}, D_{13}, D_{23}=0.039,0.0535,0.0464$.

To exclude influence of grey and white background we form the barcodes of the face images with black background (Figure 13).
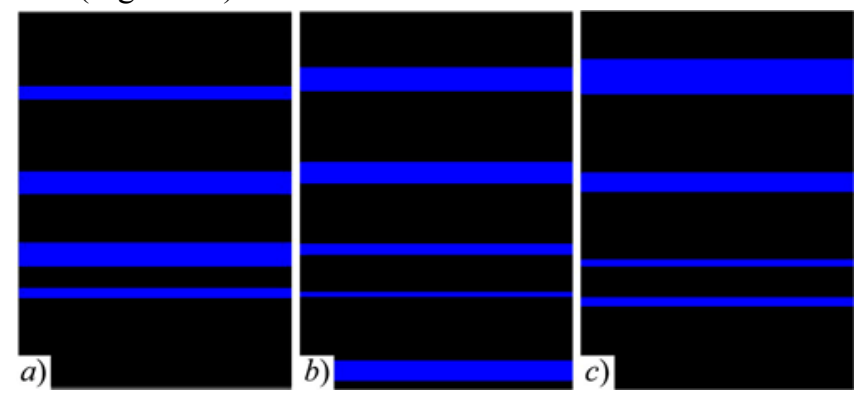

Fig. 13. Blue bars with black background of face images: a) 1 a; b) $7 \mathrm{a}$; c) 17 a

Applying the mean intensity function in rows for these barcode images we get three values of the similarity function (14): $D_{12}, D_{13}, D_{23}=0.0202,0.0205,0.0195$.

Distances between the blues middle lines, distances between the red middle lines, corresponding heights and widths of bars are features for further investigation.

\section{Conclusions}

Algorithm for image intensity and cumulative histogram approximation based on piecewise linear approximation was developed and realized. The method was used for face image approximation and multilevel segmentation to obtain coordinate and dimension of the main object of the face image. These coordinates were used to get the barcodes presentation of face images. New face features are simple for calculation and are planned for identification systems.

\section{References}

1. Liao, P. S, Chen, T. S., \& Chung, P. C. (2001). A fast algorithm for nultilevel thresholding. Journal of Imformation Science and Engineering, $\quad 17, \quad 713-727$. https://doi.org/10.6688/JISE.2001.17.5.1
2. Huang, Y., \& Wang, S. (2008). Multilevel thresholding methods for image segmentation with Otsu based on QPSO. Congress on Image and Signal Processing, 701-705. https://doi.org/10.1109/CISP.2008.76

3. Arora, S., Acharya, J., Verma, A., \& Panigrahi, P. K. (2006). Multilevel thresholding for image segmentation through a fast statistical recursive algorithm. Pattern Recognition Letters, 29(2), 119-125. https://doi.org/10.1016/j.patrec.2007.09.005

4. Mousavirad, S. J., \& Ebrahimpour-Komleh, H. (2017). Multilevel image thresholding using entropy of histogram and recently developed population-based metaheuristic algorithms. Evolutionary Intelligence, 10(1-2), 45-75. https://doi.org/10.1007/s12065-017-0152-y

5. Arifin, A. Z., \& Asano, A. (2006). Image segmentation by histogram thresholding using hierarchical cluster analysis. Pattern Recognition Letters, 27(13), 1515-1521. https://doi.org/10.1016/i.patrec.2006.02.022

6. Li, S. Z., \& Jain, A. K. (2011). Handbook of face recognition. Springer. London, 699 p. https://doi.org/10.1007/978-0-85729-932-1

7. Oravec, M. (2010). Face recognition. Open access peer-reviewed Edited. Vol. 4, Slovakia, 404 p. https://doi.org/10.5772/207

8. Delac, K., Grgic, M., \& Bartlett, M. S. (2008). Recent advanced in face recognition. Open access peer-reviewed Edited Volume, Croatia. 236 p. https://doi.org/10.5772/94.

9. Ravat, R., \& Dhanda, N. (2015). Performance comparison of face recognition algorithm based on accuracy rate. International Journal of Advanced Research in Computer and Communication Engineering, 4(5), 323-326. https://doi.org/10.17148/IJARCCE.2015.4572

10. Melnyk, R., \& Kalychak, Yu. (2020). Face image barcodes by distributed cumulative histogram and clustering. IEEE 15th International Conference on Advanced Trends in Radioelectronics, Telecommunications and Computer Engineering (TCSET), 346349. https://doi.org/10.1109/TCSET49122.2020.235589

11. Ramer, U. (1972). An iterative procedure for the polygonal approximation of plane curves. Computer Graphics and Image Processing, 1(3), 244-256. https://doi.org/10.1016/S0146-664X(72)80017-0

12. Douglas, D., \& Peucker, T. (1973). Algorithms for the reduction of the number of points required to represent a digitized line or its caricature. The Canadian Cartographer, 10(2), 112-122. https://doi.org/10.3138/FM57-6770-U75U-7727

13. FEI Face Database. (2020). Last accessed: May 15, 2020. Retrieved from: https://fei.edu.br.

Р. А. Мельник, Р. І. Квіт, Т. М. Сало

Національний університет "Львівська політехніка", м. Львів, Україна

\section{ВИДІЛЕННЯ ОЗНАК ПРОФІЛІВ ЗОБРАЖЕННЯ ОБЛИЧЧЯ ДЛЯ} СИСТЕМ РОЗПІЗНАВАННЯ

Об'єктом дослідження є алгоритм кусково-лінійної апроксимації за застосування його до виділення ознак та стиснення зображень обличчя. Одним з проблемних місць є отримання оптимального співвідношення ступеня стиснення та точності відтворення зображення, а також точності отриманих ознак обличчя, які можна застосувати для пошуку осіб у базах даних. Основними характеристиками зображення обличчя $є$ координати та розмір очей, рота, носа та інших об'єктів уваги. Розміри, відстані між ними, а також їх відношення теж утворюють набір характеристик. Для виявлення та визначення цих особливостей використовують алгоритм кусково-лінійної апроксимації. По-перше, його застосовують для апроксимації зображення обличчя, щоб отримати графік силуету справа наліво i, по-друге, для апроксимованих фрагментів обличчя, щоб отримати силуети обличчя зверху вниз. Метою наступного етапу є реалізація багаторівневої сегментації апроксимованих зображень, щоб покрити їх прямокутниками різної інтенсивності. Завдяки своїй формі вони названі штрих-кодами. Ці три етапи алгоритму обличчя подаються двома зображеннями штрих-кодів: вертикальним і горизонтальним. За цим матеріалом розраховують ознаки обличчя. Функцію середньої інтенсивності в рядку або стовпці використовують для формування об'єкта апроксимації та як інструмент для вимірювання значень характеристик зображення обличчя. Додатково розраховують ширини штрих-кодів та відстані між ними. Наведено експериментальні результати з обличчями 3 відомих баз даних. Кусково-лінійну апроксимацію використано для стиснення зображень обличчя. Експериментами показано, як змінюється точність апроксимації залежно від ступеня стиснення зображення. Метод має лінійну складність алгоритму залежно від кількості пікселів у зображенні, що дає змогу його тестувати для великих даних. Знаходження координат об'єкта синхронізації, наприклад очей, дає змогу обчислити всі відстані між об'єктами уваги на обличчі у відносній формі. Розроблене програмне забезпечення має параметри керування для виконання досліджень.

Ключові слова: апроксимація; кусково-лінійна функція; кумулятивна гістограма; багаторівнева сегментація; середня інтенсивність. 